\title{
Intestinal metaplasia and Helicobacter pylori: an endoscopic bioptic study of the gastric antrum
}

\author{
M E Craanen, W Dekker, P Blok, J Ferwerda, G N J Tytgat
}

\begin{abstract}
To study the relationship between intestinal metaplasia and Helicobacter pylori infection, 2274 gastroscopic antral biopsies taken from 533 patients were examined. Overall, intestinal metaplasia was found in 135 patients (25.3\%) and $H$ pylori in 289 patients (54.2\%). The prevalence of intestinal metaplasia and $H$ pylori was age related, being more common in patients $\geq \mathbf{5 0}$ years compared with patients $<50$ years (intestinal metaplasia, $p<0.001$ and $H$ pylori, $\mathbf{p}<0.05)$. Intestinal metaplasia was found more often in $H$ pylori positive patients compared with $H$ pylori negative patients $(33.9 \% v 15.2 \%, \mathrm{p}<0.001)$. The mean age of intestinal metaplasia positive patients who were also $H$ pylori positive was 64 (13.3) years, whereas the mean age of intestinal metaplasia positive patients who were $\boldsymbol{H}$ pylori negative was $72(14.7)$ years $(p<0.005)$. The extent of intestinal metaplasia was not statistically different in the latter two groups. Although our data do not prove a causal relationship between $\boldsymbol{H}$ pylori infection and the histogenesis of intestinal metaplasia it is suggested that $H$ pylori infection is an important factor in the development of intestinal metaplasia, which is generally recognised as a precursor lesion of intestinal type gastric carcinoma.
\end{abstract}

In 1983 Warren and Marshall reported unidentified curved bacilli in gastric antral biopsies from patients with chronic active gastritis and peptic ulcer disease. ' This bacterium, first called Campylobacter pylori, has recently been renamed Helicobacter pylori. Since their report many studies have confirmed a close association between the presence of $H$ pylori in the gastric mucosa, chronic active gastritis and gastric and duodenal ulcers..$^{2-8}$

Detailed studies of the gastric mucosa in populations with a high risk of developing gastric carcinoma have described a series of lesions which may represent a continuum of change from normal to carcinoma, ${ }^{9}$ starting with chronic active gastritis which may progress to chronic atrophic gastritis with intestinal metaplasia and finally to dysplasia and gastric carcinoma. ${ }^{10}$

Based on these data, we speculated that there might be a relationship between $H$ pylori and intestinal metaplasia in the gastric mucosa, thereby assuming that Helicobacter gastritis might evolve into intestinal metaplasia. Because both show a predilection for the gastric antrum $^{21112}$ which in case of $H$ pylori may be related to a specific glycerolipid receptor, ${ }^{13}$ we undertook this endoscopic bioptic study of the gastric antrum to assess whether intestinal metaplasia can be more often found in positive patients as compared with $H$ pylori negative patients.

\section{Methods}

\section{PATIENTS}

All patients reported in this study were referred to the endoscopy department of St Elisabeth's of Groote Gasthuis for upper gastro-intestinal endoscopy on clinical grounds between December 1988 and June 1990. Patients requiring emergency endoscopy or having undergone , previous gastric surgery were excluded.

Endoscopy was carried out after an overnight fast. The endoscopes (Olympus GIF Q10, Q20) were cleaned with detergent, disinfected with $70 \%$ ethanol, and rinsed with sterile water after each examination. Only patients with macroscopically suspected antral gastritis or any other antral lesion were included, resulting in a total of 533 patients. The number of antral biopsies taken depended on the gross macroscopic diagnosis made by the endoscopists and were taken from the lesions and adjacent mucosa along the lesser and/or greater curvature within $4 \mathrm{~cm}$ of the pylorus. All biopsies were fixed in $10 \%$ formalin, embedded in paraffin and cut at $5 \mu$. Routine staining with haematoxylin and eosin $(H \& E)$ was done for histopathologic diagnosis and detection of $H$ pylori. In case of doubt as to whether $H$ pylori was present, additional Giemsa staining was carried out. $H$ pylori was judged to be absent if both staining methods were negative for $H$ pylori. The extent of intestinal metaplasia in the gastric biopsies was cumulatively graded as follows: (0) none; (1) mild degree, consisting of a few tubules to one third of the total area biopsied; (2) moderate degree, consisting of one third to two thirds of the total area biopsied; (3) severe degree, consisting of two thirds or more of the total area biopsied.

The $\chi^{2}$ and two-tailed Student's $t$ test were used for statistical analysis of the data collected.

\section{Results}

HISTOPATHOLOGIC DIAGNOSIS

Two thousand two hundred and seventy four antral biopsies obtained from 533 patients were examined. Both gastritis and gastric ulcer were significantly associated with $H$ pylori as compared with normal gastric mucosa $(\mathrm{p}<0 \cdot 001)$ (Table I).

RELATIONSHIP BETWEEN AGE INTESTINAL METAPLASIA AND HELICOBACTER PYLORI

The prevalence of intestinal metaplasia in gastric antral biopsies increased from $0 \%$ in the age

\author{
Correspondence to: \\ $M$ E Craanen, Department of \\ Gastroenterology and \\ Medical Centre, Meibergdreef \\ 9, 1105AZ, A \\ Accepted for publication \\ 2 April 1991 \\ Medicine, St Elisabeth' \\ Hepatology, Academic \\ Medical Centre, \\ Amsterdam, The \\ Netherlands
}


TABLE I Characteristics of patients according to diagnosis (533)

\begin{tabular}{|c|c|c|c|c|c|c|c|c|}
\hline $\begin{array}{l}\text { Histological } \\
\text { diagnosis }\end{array}$ & $\begin{array}{l}\text { Patients } \\
(n)\end{array}$ & $\begin{array}{l}\text { Biopsies } \\
\text { (total) }\end{array}$ & $\begin{array}{l}\text { Biopsy } \\
\text { (range) }\end{array}$ & $\begin{array}{l}\text { Mean no. } \\
\text { biopsy }(S D)\end{array}$ & $\begin{array}{l}\text { Age } \\
\text { (range) }\end{array}$ & $\begin{array}{l}\text { Mean age } \\
(S D)\end{array}$ & $\begin{array}{l}\text { H pylori } \\
\text { positive } \\
(\% n)\end{array}$ & $\begin{array}{l}\text { Intestinal } \\
\text { metaplasia } \\
\text { positive } \\
(\% n)\end{array}$ \\
\hline $\begin{array}{l}\text { Normal } \\
\text { Erosion } \\
\text { Gastritis } \\
\text { Gastric ulcer }\end{array}$ & $\begin{array}{r}126 \\
26 \\
298 \\
67\end{array}$ & $\begin{array}{r}359 \\
82 \\
1082 \\
581\end{array}$ & $\begin{array}{l}1-9 \\
1-10 \\
1-14 \\
3-30\end{array}$ & $\begin{array}{l}2 \cdot 9(1 \cdot 8) \\
3 \cdot 2(2 \cdot 2) \\
3 \cdot 6(2 \cdot 8) \\
8 \cdot 7(3 \cdot 8)\end{array}$ & $\begin{array}{l}18-88 \\
27-64 \\
20-93 \\
23-90\end{array}$ & $\begin{array}{l}51 \cdot 6(17 \cdot 7) \\
60 \cdot 0(15 \cdot 7) \\
58 \cdot 4(16 \cdot 3) \\
63 \cdot 8(15 \cdot 8)\end{array}$ & $\begin{array}{c}2(1 \cdot 6 \%) \\
12(46 \cdot 1 \%) \\
228(76 \cdot 5 \%) \\
47(70 \cdot 2 \%)\end{array}$ & $\begin{array}{c}0(0 \%) \\
1(3 \cdot 9 \%) \\
88(29 \cdot 5 \%) \\
37(55 \cdot 2 \%)\end{array}$ \\
\hline $\begin{array}{l}\text { Intestinal type } \\
\text { Diffuse type }\end{array}$ & $\begin{array}{r}8 \\
8 \\
533\end{array}$ & $\begin{array}{r}71 \\
99 \\
2274\end{array}$ & $\begin{array}{l}5-13 \\
5-19\end{array}$ & $\begin{array}{r}8 \cdot 9(2 \cdot 5) \\
12 \cdot 4(4 \cdot 1)\end{array}$ & $\begin{array}{l}67-87 \\
49-80\end{array}$ & $\begin{array}{l}77 \cdot 5(6 \cdot 5) \\
57 \cdot 9(11)\end{array}$ & $\begin{array}{c}0(0 \%) \\
0(0 \%) \\
289(54 \cdot 2 \%)\end{array}$ & $\begin{array}{c}8(100 \%) \\
1(12 \cdot 5 \%) \\
135(25 \cdot 3 \%)\end{array}$ \\
\hline
\end{tabular}

group $<20$ years to $46.6 \%$ in the age group $\geq 80$ years (Table II). When all patients were divided into two age groups - namely, (i) $<50$ years $(163$ and (ii) $\geq 50$ years ( 370 ), intestinal metaplasia was found significantly more often in patients $\geq 50$ years ((i) $10.4 \%$, (ii) $31.9 \%, \mathrm{p}<0.001$ ) (Table III).

The prevalence of $H$ pylori in gastric antral biopsies increased from $0 \%$ in the age group $<20$ years to $65 \cdot 1 \%$ in the age group 50 to 59 years, after which a decrease to $44.8 \%$ in the age group $\geq 80$ years was observed (Table II). When all patients were divided into the same two age groups - namely (i) $<50$ years and (ii) $\geq 50$ years, $H$ pylori was found significantly more often in patients $\geq 50$ years ((i) $46 \cdot 6 \%$, (ii) $57 \cdot 6 \%$, $\mathrm{p}<0.05$ ) (Table IV).

RELATIONSHIP BETWEEN INTESTINAL METAPLASIA AND HELICOBACTER PYLORI

Overall, $H$ pylori was found in 289 patients $(54 \cdot 2 \%)$, whereas intestinal metaplasia was found in 135 patients $(25 \cdot 3 \%)$. When all 533

TABLE II Prevalence of intestinal metaplasia (IM) and Helicobacter pylori (HP) according to age group (533)

\begin{tabular}{lccc}
\hline $\begin{array}{l}\text { Age group } \\
(y r)\end{array}$ & $\begin{array}{l}\text { Patients } \\
(n)\end{array}$ & $\begin{array}{l}\text { Intestinal metaplasia } \\
\text { positive patients }(\% n)\end{array}$ & $\begin{array}{l}\text { H pylori positive } \\
\text { patients }(\% n)\end{array}$ \\
\hline$<20$ & 2 & $0(0 \%)$ & $0(0 \%)$ \\
$20-29$ & 34 & $1(2 \cdot 9 \%)$ & $12(35 \cdot 3 \%)$ \\
$30-39$ & 41 & $3(7 \cdot 3 \%)$ & $21(51 \cdot 2 \%)$ \\
$40-49$ & 86 & $13(15 \cdot 1 \%)$ & $43(50 \%)$ \\
$50-59$ & 106 & $25(23 \cdot 6 \%)$ & $69(65 \cdot 1 \%)$ \\
$60-69$ & 114 & $28(24 \cdot 6 \%)$ & $66(57 \cdot 9 \%)$ \\
$70-79$ & 92 & $38(41 \cdot 3 \%)$ & $52(56 \cdot 5 \%)$ \\
$\geq 80$ & 58 & $27(46 \cdot 6 \%)$ & $26(44 \cdot 8 \%)$ \\
& 533 & $135(25 \cdot 3 \%)$ & $289(54 \cdot 2 \%)$ \\
\hline
\end{tabular}

$\%$ in parenthesis is related to number of patients per age group.

TABLE III Relationship between age and prevalence of intestinal metaplasia in the gastric antrum (533)

\begin{tabular}{llll}
\hline $\begin{array}{l}\text { Age group } \\
\text { (yr) }\end{array}$ & Total & $\begin{array}{l}\text { Intestinal } \\
\text { metaplasia positive } \\
\text { patients }(\boldsymbol{n})\end{array}$ & $\begin{array}{l}\text { Intestinal } \\
\text { negative } \\
\text { patients }(n)\end{array}$ \\
\hline$<50$ & 163 & 17 & 146 \\
$\geq 50$ & 370 & 118 & 252 \\
& 533 & 135 & 398 \\
\hline
\end{tabular}

$\chi^{2}$ test $; \mathrm{p}<0.001$.

TABLE IV Relationship between age and prevalence of Helicobacter pylori in the gastric antrum (533)

\begin{tabular}{llll}
\hline & & $\begin{array}{l}\text { H pylori } \\
\text { positive } \\
\text { patients }(n)\end{array}$ & $\begin{array}{l}\text { H pylori } \\
\text { negative } \\
\text { patients }(n)\end{array}$ \\
\hline yr) & Total & 76 & 87 \\
\hline 50 & 163 & 76 & 157 \\
$\geq 50$ & 370 & 213 & 244 \\
\hline
\end{tabular}

$\chi^{2}$ test $; \mathrm{p}<0.05$ patients were divided into two groups - namely, (i) $H$ pylori positive (289) and (ii) $H$ pylori negative (244), intestinal metaplasia was significantly found more often in the $H$ pylori positive group ((i) $33.9 \%$, (ii) $15 \cdot 2 \%, \mathrm{p}<0.001$ ) (Table V). When all 135 intestinal metaplasia positive patients were divided into two groups according to $H$ pylori status, we found that the mean age of the intestinal metaplasia positive $H$ pylori positive group (98) was significantly lower than that of the intestinal metaplasia positive $H$ pylori negative group (37), $(64(13 \cdot 3)$ years $v 72(14 \cdot 7)$ years, $\mathrm{p}<0.005$ ) (Table VI).

The mean age of intestinal metaplasia positive patients with intestinal type carcinoma (eight) was significantly higher than that of all other intestinal metaplasia positive patients (127) namely, $77.5(6.5)$ years $v 65.8(14.2)$ years $(\mathrm{p}<0.025)$. As these eight were all $H$ pylori negative, this could possibly explain the mean age difference found between the intestinal metaplasia positive $H$ pylori positive and intestinal metaplasia positive $H$ pylori negative group. Even after having excluded all patients with intestinal-type gastric carcinoma, however, (eight) yielding a total of 127 intestinal metaplasia positive patients, the mean age of $H$ pylori positive patients was still significantly lower than that of the $H$ pylori negative patients ((i) $64(13 \cdot 3)$ years, (ii) $71 \cdot 1(15 \cdot 6)$ years, $0.005<\mathrm{p}<0.01)$.

The extent of intestinal metaplasia in the intestinal metaplasia positive $H$ pylori positive and intestinal metaplasia positive $H$ pylori negative group did not differ in a statistically significant way. When moderate and severe intestinal metaplasia were grouped together, $20.4 \%$ of

TABLE V Relationship between intestinal metaplasia and Helicobacter pylori in the gastric antral mucosa (533)

\begin{tabular}{llll}
\hline & $\begin{array}{l}\text { Patients } \\
\text { (total) }\end{array}$ & $\begin{array}{l}\text { H pylori } \\
\text { positive } \\
\text { patients }(n)\end{array}$ & $\begin{array}{l}\text { H pylori } \\
\text { negative } \\
\text { patients }(n)\end{array}$ \\
\hline $\begin{array}{l}\text { Intestinal metaplasia } \\
\text { positive }\end{array}$ & 135 & 98 & 37 \\
$\begin{array}{l}\text { Intestinal metaplasia } \\
\text { negative }\end{array}$ & 398 & 191 & 207 \\
& 533 & 289 & 244 \\
\hline
\end{tabular}

$\chi^{2}$ test; $\mathrm{p}<0.001$

TABLE VI Mean age of intestinal metaplasia positive patients according to Helicobacter pylori status (135)

\begin{tabular}{llll}
\hline & $\begin{array}{l}\text { Patients } \\
\text { (total) }\end{array}$ & $\begin{array}{l}\text { H pylori } \\
\text { positive } \\
\text { patients }(n)\end{array}$ & $\begin{array}{l}\text { H pylori } \\
\text { negative } \\
\text { patients }(n)\end{array}$ \\
\hline $\begin{array}{l}\text { Patients (n) } \\
\text { Age range (yr) }\end{array}$ & 135 & 98 & 37 \\
Mean age(SD) & $23-93$ & $33-88$ & $23-93$ \\
\hline
\end{tabular}

$\star$ Student's $t$ test; $\mathrm{p}<0.005$. 
TABLE VII Extent of intestinal metaplasia according to Helicobacter pylori status in intestinal metaplasia positive patients (135)

\begin{tabular}{lll}
\hline Extent intestinal metaplasia & H pylori positive & H pylori negative \\
\hline Mild & $78(79 \cdot 6 \%)$ & $25(67 \cdot 6 \%)$ \\
Moderate & $16(16 \cdot 3 \%)$ & $11(29 \cdot 7 \%)$ \\
Severe & $4(4 \cdot 1 \%)$ & $1(2 \cdot 7 \%)$ \\
& $98(100 \%)$ & $37(100 \%)$ \\
\hline
\end{tabular}

$\chi^{2} 0 \cdot 2<\mathrm{p}<0 \cdot 3$

intestinal metaplasia positive $H$ pylori patients and $32.4 \%$ of intestinal metaplasia positive $H$ pylori negative patients showed this extent of intestinal metaplasia $(0 \cdot 2<\mathrm{p} \leq 0 \cdot 3)$ (Table VII)

\section{Discussion}

This study again confirms the strong association of $H$ pylori with gastritis and gastric ulcer and our results compare favourably with the results reported by others. ${ }^{14-17}$ Our data also substantiate those of others ${ }^{1819}$ showing that the prevalence of $H$ pylori increases with age which suggests age related acquisition of $H$ pylori infection. In view of this, it is of interest that intestinal metaplasia and gastritis are also well known to be age related, both being more common in the older age groups. ${ }^{2021}$

In 1965 Lauren divided advanced gastric carcinoma into two main types - namely, 'intestinal' and 'diffuse' type carcinoma, which differ not only morphologically but also in their clinical and epidemiological characteristics. ${ }^{22}$ Moreover, a different histogenetic process has been postulated by many authors since Morson pointed out that intestinal type gastric carcinomas might arise from areas with intestinal metaplasia. ${ }^{23}$ Although the exact relationship between intestinal metaplasia and gastric carcinoma has still not been elucidated, it is suggested that intestinal type gastric carcinoma originates from intestinal metaplasia and that diffuse type gastric carcinoma originates in normal gastric mucosa, with no precursor lesion being identified yet. ${ }^{24-26}$ Our finding that all patients with intestinal type carcinoma were found to be intestinal metaplasia positive in contrast with one of eight patients with diffuse type carcinoma lends further support to this theory.

From detailed histological studies it is known that the process leading from chronic active gastritis through the stages of chronic atrophic gastritis, intestinal metaplasia and dysplasia to carcinoma takes a long time - that is, 16-24 years. ${ }^{27}$ Our finding that intestinal metaplasia was found significantly more often in the gastric antrum of $H$ pylori positive patients as compared with $H$ pylori negative patients may turn out to be an important observation because it suggests that $H$ pylori related gastritis may evolve into intestinal metaplasia. Since the time of colonisation with $H$ pylori appears to be the crucial factor, the occurrence of $H$ pylori related gastritis at a young age, eventually evolving into intestinal metaplasia at a younger age, might render such individuals at greater risk for developing gastric cancer of the intestinal type over a longer period of life span. Within this realm, the case report by Scott et al is of great importance. Their study of a gastric cancer family showed that of the eight children, five $(63 \%)$ had $H$ pylori related chronic atrophic gastritis (age at diagnosis 10.26 years) and in three of those five $60 \%$ ) intestinal metaplasia developed, at 21,23 , and 34 years. In all three intestinal metaplasia was confined to the gastric antrum. They postulate that $H$ pylori acts as a promoter in the progression from normal to metaplastic epithelium, possibly by inducing a hyperproliferative state in the inflamed gastric mucosa. ${ }^{28}$ In view of their report, the treatment of $H$ pylori related gastritis, leading to eradication of the microorganism, might be of help in removing a potential risk factor in gastric cancer prone patients. At present the concept that $H$ pylori and intestinal metaplasia are related is still a subject of much debate. This is highlighted by the controversy in the major classifications of chronic gastritis, concerning the aetiology of intestinal metaplasia. In the classification by Whitehead, based on morphologic criteria, the major categories of gastritis are thought to reflect increasingly severe changes in a progressive process starting with superficial gastritis gradually evolving into chronic atrophic gastritis with intestinal metaplasia. A separate entity, socalled gastric atrophy, was introduced to describe biopsies showing marked glandular atrophy, widespread intestinal metaplasia and near absence of inflammation. ${ }^{29}$ The classification by Cheli and Giacosa regarded the latter entity merely as an end stage in the spectrum of chronic atrophic gastritis. ${ }^{30}$ Although these classifications brought a more uniform histologic reporting, they did not add anything to the understanding of the pathogenetic mechanisms involved. The first attempt in addressing this important topic was the classification by Strickland and Mackay, which was further expanded by Glass and Pitchumoni. ${ }^{31}$ Both stressed the importance of the topographical distribution of chronic atrophic gastritis in relation to the underlying aetiopathogenetic mechanisms involved. One should note, however, that these classifications were proposed in the 'pre $H$ pylori era'. The discovery of $H$ pylori led Wyatt and Dixon to propose another aetiopathogenetic classification taking into account the pivotal role of $H$ pylori in the process of gastric inflammation. ${ }^{33}$ In the classifications briefly discussed so far, intestinal metaplasia is considered to be more or less a sequel to inflammation and part of a progressive process. This leaves room for the concept that intestinal metaplasia might be a result of $H$ pylori related gastritis as our data suggest.

In the classification by Correa, ${ }^{3+}$ recently revised, ${ }^{35}$ and in the classification by Yardley, ${ }^{36}{ }^{37}$ however, the presence of intestinal metaplasia in gastric biopsies indicate an aetiology for gastritis distinct from $H$ pylori. In their classifications $H$ pylori is related to diffuse antral gastritis and chronic non-specific gastritis respectively. Both have in common that intestinal metaplasia is typically absent or minimal. In contrast, it is the multifocal atrophic gastritis in Correa's classification corresponding to the meta plastic atrophic gastritis type B in Yardley's classification, which is often accompanied by intestinal metaplasia. It is thought that this type of chronic gastritis is the result of environmental agents and/or dietary 
factors like excessive intake of salty foods and nitrates, deficiency in fresh fruits and leafy vegetables. ${ }^{35-39}$ Adopting their classification implies that gastritis, in which the concomitant presence of $H$ pylori and intestinal metaplasia is demonstrated, must have a dual aetiology.

This controversy, whether or not intestinal metaplasia is a result of $H$ pylori related gastritis, can only be solved in long term follow up studies. Interestingly, the longitudinal study by Kekki $e t$ $a l$ showed that non-atrophic and non-metaplastic chronic gastritis can evolve into chronic atrophic gastritis with intestinal metaplasia. ${ }^{40}$

The interpretation of our finding that the mean age of intestinal metaplasia positive patients was significantly lower when they were also $H$ pylori positive as compared with $H$ pylori negative patients is rather complex. Of course, it is tempting to speculate that $H$ pylor $i$ accelerates the process leading to intestinal metaplasia, but there are certain other aspects to be considered. First, because $H$ pylori is only found on foveolar gastric epithelium, a difference in the extent of intestinal metaplasia - an inhospitable site for $H$ pylori - in the intestinal metaplasia positive $H$ pylori negative group as compared with the intestinal metaplasia positive $H$ pylori positive group might explain the age difference. Our data show, however, that the extent of intestinal metaplasia in both groups does not significantly differ. This suggests that the age difference found cannot be explained on the basis of a difference in extent of intestinal metaplasia. Second, our study is not a follow up cohort study, so we are neither informed about whether the intestinal metaplasia positive $H$ pylori negative group has never been colonised with $H$ pylori nor are we informed about the time of colonisation with $H$ pylori in the intestinal metaplasia positive $H$ pylori positive group. Third, the greater frequency of antibiotics use among older age groups might be a confounding factor as this may have led to the eradication of $H$ pylori. Finally, we must stress an inherent flaw of any endoscopic bioptic study, as these studies create the possibility of sampling error. Therefore, although there is a significant age difference between intestinal metaplasia positive $H$ pylori positive and intestinal metaplasia positive $H$ pylori negative patients, its meaning remains unsolved in our study and other studies are necessary for its correct interpretation. The possibility remains, however, that early acquisition of $H$ pylori not only leads to early development of intestinal metaplasia but may even accelerate the development of intestinal metaplasia.

In conclusion, although our data do not prove a causal relationship between $H$ pylori infection and the histogenesis of intestinal metaplasia, we suggest that $H$ pylori plays an important role in the development of intestinal metaplasia in the gastric mucosa. Whether $H$ pylori has to be present at all times during this process or is only necessary as a 'trigger', needs further research.

1 Warren JR, Marshall BJ. Unidentified curved bacilli on gastric epithelium in active chronic gastritis. Lancet 1983; i: 1273-5.

2 Blaser MJ. Gastric Campylobacter-like organism, gastritis and peptic ulcer disease. Gastroenterology 1987; 93: 371-83.
3 Rauws EAJ, Langenberg W, Houthoff $\mathrm{HJ}$, Zanen HC, Tytgat GNJ. Campylobacter pyloridis-associated chronic active antral gastritis: a prospective study of its prevalence and the effects of anti-bacterial and anti-ulcer treatment. Gastroenterology 1988; 94: 33-40.

4 Marshall BJ, Armstrong JA, McGechie DB, Glancy RJ. Attempt to fulfil Koch's postulates for pyloric CampyloAttempt to fulfil Koch's postulates

5 Morris A, Nicholson G. Ingestion of Campylobacter pyloridis causes gastritis and raised fasting gastric $\mathrm{pH}$. Am $\mathcal{F}$ Gastroenterol 1987; 82: 192-9.

6 Graham DY. Campylobacter pylori and peptic ulcer disease. Gastroenterology 1989; 96: 615-25.

7 Marshall BJ, Goodwin CS, Warren JR, et al. Prospective double-blind trial of duodenal relapse after eradication of Campylobacter pylori. Lancet 1988; ii: 1437-42.

8 Rauws EAJ, Tytgat GNJ. Cure of duodenal ulcer associated with eradication of Helicobacter pylori. Lancet 1990; 335 1233-5.

9 Correa P, Cuello C, Duque E, et al. Gastric cancer in Columbia. III. Natural history of precursor lesions. $\mathcal{F}$ Natl Cancer Inst 1976; 57: 1027-35.

10 Correa P. A human model of gastric carcinogenesis. Cancer Res 1988; 48: 1319-26.

11 Stemmermann GN, Hayashi T. Intestinal metaplasia of the gastric mucosa: a gross and microscopic study of its distribution in various disease states. $\mathcal{F}$ Natl Cancer Inst 1968; 41: 627-34.

12 Hattori T, Fujita S. Tritiated thymidine autoradiographic study on histogenesis and spreading of intestinal metaplasia in human stomach. Pathol Res Pract 1979; 164: 214-37.

13 Lingwood CA, Law H, Pellizari A, Sherman P, Drumm B. Gastric glycerolipid as a receptor for Campylobacter pylori. Lancet 1989; i: 238-41.

14 Booth L, Holdstock G, MacBride H, et al. Clinical importance of Campylobacter pyloridis and associated serum IgG and IgA antibody responses in patients undergoing upper gastrointestinal endoscopy. F Clin Pathol 1986; 39: 215-9.

15 Price AB, Levi J, Dolby JM, et al. Campylobacter pyloridis in peptic ulcer disease: microbiology, pathology and scanning electron microscopy. Gut 1985; 26: 1183-8.

16 McNulty CAM, Watson DM. Spiral bacteria of the gastric antrum. Lancet 1984; i: 1068-9.

17 Von Wulffen H, Heesemann J, Butzow GH, et al. Detection of Campylobacter pyloridis in patients with antrum gastritis and peptic ulcers by culture, complement fixation test, and immunoblot. F Clin Microbiol 1986; 41: 653-9.

18 Jones DM, Eldridge J, Fox AJ, Sethi P, Whorwell PJ. Antibody to the gastric Campylobacter-like organism ('Campylobacter pyloridis')-clinical correlations and distribution in the normal population. 7 Med Microbiol 1986; 22: $57-62$.

19 Perez-Perez GI, Dworkin BM, Chodos JE, Blaser MJ. Campylobacter pylori antibodies in humans. Ann Intern Med 1988 109: 11-7.

20 Imai $\mathrm{T}$, Maruyama $\mathrm{H}$. Time trend in the prevalence of intestinal metaplasia. Cancer 1983; 52: 353-61.

21 Siurala M, Isokoski M, Varis K, Kekki M. Prevalence of gastritis in a rural population. Scand F Gastroenterol 1968; 3: 211-23.

22 Lauren $P$. The two histological main types of gastric carcinoma: diffuse and so-called intestinal-type carcinoma. Acta Pathol Microbiol Scand 1965; 64: 31-49.

23 Morson BC. Carcinoma arising from areas of intestinal metaplasia in the gastric mucosa. Br 7 Cancer 1955; 9: 377-85.

24 Nakamura K, Sugano H, Takagi K. Carcinoma of the stomach in incipient phase: its histogenesis and histological appearances. Gann 1968; 59: 251-8.

25 Hirota T, Itabashi M, Susuki K, Yoshida S. Clinicopathologic study of minute and small early gastric cancer. Pathol Annu 1980; $15: 1-19$.

26 Taki K, Kuwabara N. Studies on histogenesis of the gastric carcinoma using minute cancers. Pathol Res Pract 1981; 172: 176-90.

27 Fujita S, Takanori H. Cell proliferation, differentiation and migration in the gastric mucosa: a study of the background of carcinogenesis. In: Farber E, et al, eds. Pathophysiology of carcinogenesis in digestive organs. Tokyo: University of Tokyo Press, 1977: 21-36.

28 Scott N, Lansdown M, Diament R, et al. Helicobacter gastritis and intestinal metaplasia in a gastric cancer family [letter]. Lancet 1990; 335: 728 .

29 Whitehead R, Truelove SC, Gear MWL. The histological diagnosis of chronic gastritis in fibreoptic gastroscope biopsy specimens. F Clin Pathol 1972; 25: 1-11.

30 Cheli R, Giacosa A. Chronic atrophic gastritis and gastric mucosal atrophy - one and the same. Gastrointest Endosc 1983; 29: 23-5.

31 Strickland RG, Mackay IR. A reappraisal of the nature and significance of chronic atrophic gastritis. Dig Dis 1973; 18: 429-40.

32 Glass GB, Pitchumoni CS. Atrophic gastritis. Hum Pathol 1975; 6: 219-50.

33 Wyatt JI, Dixon MF. Chronic gastritis - a pathogenetic approach. F Pathol 1988; 154 : 113-24.

34 Correa P. The epidemiology and pathogenesis of chronic gastritis: three etiologic entities. Front Gastrointest Res 1980; 6: 98-108. 
35 Correa P. Chronic gastritis: a clinico-pathological classitication. Am f Gastroenterol 1988; 83: 504-9.

36 Paull G, Yardley JM. Pathology of C. pylori-associated gastric and esophageal lesions. In: Blaser MJ, ed. Campylobacter pylori in gastritis and peptic ulcer disease. New York: Igakupylori in gastritis and

37 Yardley JH. Pathology of chronic gastritis and duodenitis. In: Goldman H, Appelman HD, eds. Gastrointestinal pathology. Baltimore: Williams and Wilkins, 1990: 69-143.
38 Nomura A, Yamakawa $\mathrm{H}$, Ishidate $\mathrm{T}$, et al. Intestinal metaplasia in Japan: association with diet. $\mathcal{f}$ Natl Cancer Inst 1982; 68: 401-5.

39 Fontham E, Zavala D, Correa P, et al. Diet and chronic atrophic gastritis: a case-control study. $\mathcal{F}$ Natl Cancer Inst 1986; 76: 621-7.

40 Kekki $M$, Siurala $M$, Varis $K$, Sipponen $P$, Sistonen $P$, Nevanlinna RH. Classification principles and genetics of chronic gastritis. Scand $\mathcal{F}$ Gastroenterol 1987; 22 (suppl 141): 1-28. 